\title{
Correspondence
}

\section{The Fly in the Fourier}

SiR,--Long before the publication of my heresy, or odium theologicum as it has been termed (Nature, 226, 404; 1970), I realized that there would be reaction from the Establishment; however, I did not expect that this would sink to the level of an anonymous report, cited above, written, apparently, by one unversed in the pitfalls of Fourier analysis. The crystallographic "nuances" referred to are not such at all, but truisms well known to experienced structure analysts. The author of this report appears to be so stunned by the fact that someone could have the temerity to question evidence which has been presented in support of a DNA structure that he has taken leave of his objectivity. Your readers should refer to the original papers (Science, 165, 1091; 1969; 167, 1693, 1694, 1694, $1700 ; 1970)$ and not rely on your reporter's eclectic treatment of them. Thus, he states, referring to electron density difference maps: "These make the best of the data", a statement which could be made only by one unfamiliar with the details of this technique. He ropeats the fiction that there was misrepresentation of earlier results by omission of reference to difference maps, when, in fact, all parties agree that these contain no more information than do observed and calculated maps, which were found in 1091, above. He characterizes the letter by Crick (above, 1694) as an "olympian boot", but is so untutored in the nature of diffraction that he is unaware of an egregious misconception of basics in that letter (pointed out in 1700, above) which effectively rendered that boot imperceptible. He also appears to agree with Crick's view that if I am dissatisfied with the existing "canonical" DNA model I should employ my energy in attempts to construct satisfactory alternative models. But this is not the issue: it is rather like expecting someone who reacts unfavourably to an inadequate production of Die Götterdämmerung to mount his own ideal production. The real point, which your reporter so cunningly evaded, is whether the various electron density functions which have been presented as proof of a particular DNA structure do, in fact, constitute proof of that structure. The answer to this question surely should be made by "the trade" with its "crystallographic dialectic", and not by workers in an unrelated discipline.

Your reporter's view appears to be that because "the innocent bystanders" in "the outside world of molecular biology" do not understand the recondite world of X-ray crystallography, it would seem best for them to ignore the results of experiment, and believe only what they wish to believe on emotional grounds. This is indeed true innocence.

$$
\text { Yours faithfully, }
$$

JeRry DONOHUE

Department of Chemistry,

University of Pennsylvania,

Philadelphia, Pennsylvania 19104, USA.

This letter has been shown to the author of the article concerned, who replies as follows:

Dr Johnson on a celebrated occasion allowed a hot potato to fall from his mouth onto his plate with the words, "Many a lesser man, sir, would have swallowed that". Evidently this view does not commend itself to Professor Donohue, for he has swallowed his hot potato. His letter, like his reply to his critics (Science, 165, 1700; 1970 ), reiterates, but does not add to his arguments, and does not answer the charge of biased presentation of datathe failure to mention the part of an alternative structure which does not fit the data, the use of electron density contour intervals so wide as to vitiate any inferences, and so forth. Nonetheless, Professor Donohue has shifted his ground. After thundering from the rooftops to an awestruck multitude the dreadful (if uncontested) truth that the structure of DNA has not been rigorously proven, he now - a trifle disingenuously, as it seems to me-belabours me for my indelicacy in intruding into a private rift within the crystallographic family, which should not be exposed to the vulgar gaze of the scientific canaille. While adopting a posture of defiance in the face of the Establishment, he utters a plea to be judged only by "the trade" or, as it is more aptly termed, the crystallographic Establishment. For the benefit of those readers who flagged before reaching the peroration of Donohue's article (ibid., 1700), I quote: "I did not mean to imply that the X-ray data for DNA could be fitted just as well by a model with alternative base-pairing. What I said was 'The Fourier method of structure refinement has in fact contributed nothing toward either the proof of that structure nor toward the elucidation of its details'." A modest claim, perhaps, and of a truly theological character.

The essential issue, however, was whether Donohue's strictures can be said to impinge on molecular biology at large, and my argument--though as Donohue rightly implies readers can take it or leave it - was that they do not, because of the bulk and variety of the evidence on base-pairing in both DNA and RNA, and now indeed because of his failure, despite, one must suppose, fairly strenuous efforts, to produce an alternative pairing scheme that fits the data.

I am resigned to the eternal sharne of being pilloried, in company with Crick, for my inadequate grasp of basic principles of X-ray diffraction. As to the difference Fourier maps, however, and what is agreed by "all parties", I would merely direct readers' attention to the view expressed by four of the parties (ibid., 1693). Though as for Götterdämmerung-Professor Donohue, I can only surmise, sees himself as Siegfried, but who, I wonder, will be his Hagen?

\section{Bombs and Earthquakes}

SrR,-On May 9, 1970, Dr D. S. Robertson wrote to the New York Times pointing out that two severe earthquakes had followed underground nuclear explosions. Since then there has been much uninformed speculation in the press as to whether the Peruvian earthquake could have been triggered by the French nuclear test at Muroroa Atoll on the previous day (May 24, 1970). Robertson ${ }^{1}$ is reported to have stated that "it now seemed almost certain that the tests and quakes are correlated". It is the purpose of this note to produce both general and statistical arguments which lead to the opposite view.

The general reasons depend on the following arguments: the energy put into the ground by the Muroroa Atoll test (a fow kilotons in the atmosphere) would be very small compared with that generated by an earthquake of magnitude 4 of which there are an average of 10,000 a year. Tests in the atmosphere are poorly coupled to the ground and we estimate the French test on May 29 to be equivalent to a local event of magnitude not greater than $2 \cdot 5$ of which there are approximately 100,000 every year. If Robertson's conjecture were correct it would seem that earthquakes would be far more likely to be triggered by other large distant earthquakes than by nuclear bombs, but we know of no evidence or suggestions that this occurs. Small local foreshocks and aftershocks which 
often precede and follow larger earthquakes might be considered as examples of these sorts of phenomena, although we believe they are more likely to be part of the total mechanism producing the original earthquake, and in any case they are local, not distant. There is also the fact that, as we would expect, the French atmospheric nuclear tests on May 15, 22 and 29 were not detected by the Warramunga seismic array or to our knowledge by any of the other seismic stations in Australia. Our estimates lead us to believe that the ground movement it would cause in Peru would be far less than the random background move. ment (seismic noise) which is always present and certainly less than a magnitude 4 event in, say, California. Fairly large earthquakes are not uncommon in Peru; for example, a magnitude $7 \cdot 4$ event occurred on November 10, 1946, and 5.9 on July 24 and October 1,1969 . On any mechanism the time delay, of the order of a day, between the bomb and the explosion required by Robertson would be difficult to explain. Finally, we know that large underground nuclear explosions produce small local shocks ${ }^{2}$ so we should not expect small poorly coupled atmospheric explosions to produce large distant earthquakes.

Statistical evidence has already been cited by Underwood, Cleary and Read". They found that "the occurrence of largo earthquakes in the few days following an explosion is no greater than the normal level of activity". As further evidence we wish to add the following statistical argument:

Assume that earthquakes and bombs are independently distributed. Then the expected number of "coincidences", $\lambda$, due to chance is given by

$\lambda=($ No. of earthquakes $) \times($ proportion of bomb days $)$
There are forty earthquakes a year whose magnitude is 6 or greater. Since January 1964 there have been 350 nuclear explosions; that is, the proportion of bomb days is approximately 1 in 8 ;

$$
\text { therefore } \lambda=40 \times \frac{1}{8}=5
$$

On the average, we would thus expect five coincidences a year due to chance alone. The actual number of coincidences a year will be approximately a Poisson distribution with the following probabilities:

\begin{tabular}{|lccccc|}
\hline Number of coincidences a year & 3 & 4 & 5 & 6 & 7 \\
Probability & 0.13 & $0 \cdot 16$ & $0 \cdot 17$ & 0.15 & $0 \cdot 12$ \\
\hline
\end{tabular}

From this we see that $3,4,5,6$ or 7 coincidences a year are nearly equiprobable and that the probability of 3 to 7 coincidences a year is 0.73 . This means that we could expect 3 to 7 coincidences to arise by chance alone about every 1.3 years and this is what Robertson seems to have observed.

\section{Yours faithfully, \\ Gordon Newstead Margaret Pite}

Research School of Physical Sciences,

Australian National University,

Canberra, ACT, Australia.

1 Robertson, D. S., Canberra Times (Jume 8, 1970).

2 Science, 166, 601 (1969).

${ }^{3}$ Underwood, R., Cleary, J., and Read, L., Canberra Times (June 10, 1970).

\section{Announcements}

\section{University News}

Dr J. G. Thompson, at present senior research fellow at Churchill College, University of Cambridge, has been elected Rouse Ball professor of mathematics, as from January 1, 1971.

R. Buckminster Fuller, a member of the faculty of the University of Southern Illinois, will join the University of Detroit for one year as visiting professor.

Professor Robert W. Steel, professor of geography at the University of Liverpool, has been appointed a pro-vice-chancellor of that university.

Dr D. V. Bugg, principal scientific officer at the Rutherford Laboratory, has been appointed to the chair of nuclear physics at Queen Mary College, University of London. Professor S. J. G. Semple, professor of medicine at St Thomas's Hospital Medical School, has been appointed to the chair of medicine tenable at the Middlesex Hospital Medical School, and Dr K. O. Kemp, reader in structural engineering at University College London, has been appointed to the Chadwick chair of civil engineering tenable at that college. The following titles have been conferred: professor of cytochemistry, on Dr S. J. Holt in respect of his post at the Middlesex Hospital Medical School; professor of clinical anaesthesia, on Dr M. K. Sykes in respect of his post at the Royal Postgraduate Medical School; professor of planning studies, on Dr P. D. Cowan in respect of his post at University College London; professor of endocrine physiology and pharmacology, on Dr J. R. Hodges in respect of his post at the Royal Free Hospital School of Medicine; professor of erystallography, on Dr J. W. Jeffery in respect of his post at Birkbeck College; professor of theoretical computation, on Mr P. J. Landin in respect of his post at Queen Mary
College; professor of mathematics, on Dr G. L. Watson in respect of his post at University College.

Dr Clive Rosendorff, research fellow of the American Heart Foundation and the British Heart Foundation and visiting assistant professor at Yale University during 1969-70, has been appointed to the Otto Beit chair of physiology at the University of the Witwatersrand.

\section{Appointments}

Mr J. P. Graham, deputy director of research of the British Coke Research Association, has been appointerl director in succession to Dr G. W. Lee, who retired on June 30.

Mr A. F. Kelly has been appointed deputy director of the National Institute of Agricultural Botany in succession to Dr P. S. Wellington, who becomes director on October 1.

Dr John W. Fitchie, deputy director of the Fighting Vehicles Research and Development Establishment, has been appointed director of the Transport Research Assessment Group at the Ministry of Transport's Road Research Laboratory, in succession to Dr A. J. H. Hitchcock.

\section{Miscellaneous}

Dr Irmgard Flugge-Lotz, Stanford University, has received the 1970 achievement award of the Society of Women Engineers, for her significant contributions to the field of fluid mechanies, in particular wing theory and boundary layer theory.

The president of the Argonne Universities Association has announced the establishment of AUA distinguished 